\title{
A NOTE ON THE CARDIAC OUTPUT OF A SINGLE INDIVIDUAL OBSERVED OVER A PERIOD OF FIVE YEARS
}

\author{
By C. SIDNEY BURWELL AND G. CANBY ROBINSON
}

(From the Medical Clinic, Vanderbilt University Hospital)

(Received for publication July 25, 1928)

In 1924 we (1) reported the results of a study of the output of the heart in normal resting adults. At that time we commented on. the fact that two of our subjects differed in the degree of variation exhibited by their cardiac outputs at different times but under identical circumstances. We reported four observations of one individual whose cardiac output varied from 4540 to $6780 \mathrm{cc}$. per minute and five observations of another subject in whom five measurements scattered over a year varied only from 3700 to $3960 \mathrm{cc}$. per minute. Since that time further observations of the second subject have been made, with results which seem of interest sufficient to warrant recording them.

The first group of measurements was made by the method of Burwell and Robinson (2), in Baltimore, Maryland, between March, 1923 and March, 1924. The second series was carried out in Nashville, Tennessee, by the method of Bock, Field, Gildea and Lathrop (3), between January, 1927 and February, 1928. All observations were made under conditions as nearly identical as could be arranged. The measurements were made in the morning, with the subject fasting, and after he had rested for thirty minutes or more in a reclining chair.

The results are exhibited in table 1 . It will be observed first, that the pulse rate, basal metabolic rate, and respiratory quotient are remarkably constant throughout the whole series of observations. Second, the cardiac output, with the exception of three mesurements made in June, 1927 , varies only from $3620 \mathrm{cc}$. per minute to 3960 cc. per minute. The cardiac output was constant not only from day to day and year to year, but also in three successive measurements 
at $1 \frac{1}{2}$ hour intervals on January 31,1927 in which the variation in the output of the heart was only $100 \mathrm{cc}$.

This general agreement constitutes not only a demonstration of the degree of perfection of physiological regulation but also impres-

TABLE 1

The output of the heart per minute and related figures

\begin{tabular}{|c|c|c|c|c|c|c|c|c|c|c|}
\hline Date & Method & 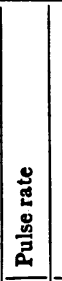 & 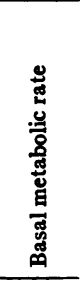 & 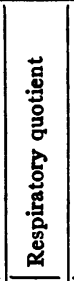 & 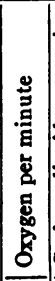 & 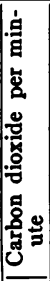 &  & 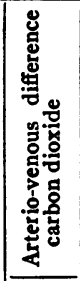 & 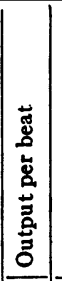 & 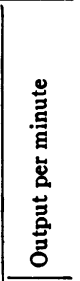 \\
\hline & & & $\begin{array}{l}\text { per cent } \\
\text { of } \\
\text { normal }\end{array}$ & & cc. & cc. & $\begin{array}{c}\text { ool- } \\
\text { wmes } \\
\text { per } \\
\text { cent }\end{array}$ & $\begin{array}{c}\text { ool. } \\
\text { umes } \\
\text { per } \\
\text { cent }\end{array}$ & cc. & $c c$. \\
\hline March 31, 1923. & $\begin{array}{c}\text { Burwell and } \\
\text { Robinson }\end{array}$ & 67 & -10 & 0.78 & 238 & 186 & 6.44 & $5.02^{*}$ & 593 & 3,700 \\
\hline April & $\begin{array}{c}\text { Burwell and } \\
\text { Robinson }\end{array}$ & 66 & -8 & $|0.85|$ & 236 & 200 & 5.91 & $5.02^{*}$ & 60 & 3,940 \\
\hline April 19, 1923 & $\begin{array}{l}\text { Burwell and } \\
\text { Robinson }\end{array}$ & 68 & -10 & 0.81 & 236 & 191 & 5.97 & $4.48^{*}$ & 58 & 3,950 \\
\hline June 2, 1923. & $\begin{array}{c}\text { Burwell and } \\
\text { Robinson }\end{array}$ & 72 & -10 & $|0.78|$ & 238 & 186 & 6.01 & $4.69^{*}$ & 553 & 3,960 \\
\hline March 13, 1924. & $\begin{array}{l}\text { Burwell and } \\
\text { Robinson }\end{array}$ & 66 & -8 & 0.78 & 248 & 193 & 6.33 & $4.94^{*}$ & 573 & $3,9.20$ \\
\hline $\begin{array}{r}\text { January } 31,192 \\
8: 30 \text { a.m..... }\end{array}$ & Bock et al. & 68 & -5 & 0.81 & 243 & 197 & $6.19^{*}$ & 5.01 & & 3,930 \\
\hline 10:00 a.m.. & Bock et al. & 68 & -4 & 0.80 & 247 & 198 & $6.46^{*}$ & 5.17 & & 3,830 \\
\hline $11: 30$ a. 1 & Bock et al. & 68 & -4 & $|0.80|$ & 249 & 199 & $6.38 *$ & 5.10 & & 3,900 \\
\hline March 21, 1927. & Bock et al. & 67 & -6 & 0.79 & 246 & 194 & $6.30^{*}$ & 4.97 & & 3,900 \\
\hline June 14, 1927. & Bock et al. & 73 & -10 & 0.81 & 232 & 188 & $4.43^{*}$ & 3.59 & 72 & 5,240 \\
\hline June 16, 1927. & Bock et al. & 67 & -10 & 0.81 & 236 & 191 & $4.77^{*}$ & 3.86 & & 4,950 \\
\hline & Bock et al. & 71 & -7 & 0.82 & 243 & 199 & $5.16^{*}$ & 4.23 & & 4,700 \\
\hline February 10,19 & Bock et al. & 65 & -8 & 0.83 & 231 & 192 & $6.38^{*}$ & 5.29 & & 3,630 \\
\hline
\end{tabular}

* Calculated.

sive evidence of the agreement in this subject, of two quite different methods of measuring the output of the heart.

Why three successive measurements during ten days in June 1927 should have given higher figures than any other of the thirteen is not known. The weather at this period was warm but the tempera- 
ture in the laboratory was only $27^{\circ} \mathrm{C}$. and the subject was not conscious of discomfort due to heat. The subject's general physical condition may have had some bearing on the result. He was tired, working long hours, and under a certain amount of mental tension. The increase in cardiac output at this time was not due to any increase in basal metabolic rate but to a fall in the arterio-venous difference. In two of these three measurements the average pulse rate was slightly above his usual basal level but not as much so as the cardiac output per minute, so that the output per beat was elevated. The peripheral blood pressure at these times showed no change from its usual level of 115 systolic and 85 diastolic pressure.

\section{SUMMARY}

Thirteen measurements of the cardiac output of a single subject over a period of five years are reported. The output of the heart remained relatively unchanged throughout that period.

\section{BIBLIOGRAPHY}

1. Burwell, C. Sidney, and Robinson, G. Canby, J. Clin. Invest., 1924, i, 87. The Gaseous Content of the Blood and the Output of the Heart in Normal Resting Adults.

2. Burwell, C. Sidney, and Robinson, G. Canby, J. Clin. Invest., 1924, i, 47. A Method for the Determination of the Amount of Oxygen and Carbon Dioxide in the Mixed Venous Blood of Man.

3. Field, H., Jr., Bock, A. V., Gildea, E. F., and Lathrop, F. L., J. Clin. Invest., 1924, i, 65. The Rate of the Circulation of the Blood in Normal Resting Individuals. 